\title{
Future Uncertainty of Sustainable Paddy Fields in Bengkulu Indonesia
}

\author{
Muhammad Faiz Barchia ${ }^{1 *}$, Satria Putra Utama ${ }^{2}$, Ridha Rizki Novanda ${ }^{3}$, Andi Ishak ${ }^{4}$ \\ ${ }^{I}$ Soil Science Department, Faculty of Agriculture, University of Bengkulu, Indonesia \\ ${ }^{2,3}$ Socio-economics Department, Faculty of Agriculture, University of Bengkulu, Indonesia \\ ${ }^{4}$ Bengkulu Assessment Institute for Agricultural Technology, Indonesia \\ *Corresponding author. Email: faizbarchia@unib.ac.id
}

\begin{abstract}
Main constraint of rice cultivation for staple food supply and national food security as sustainable agriculture indicator in Indonesia is reduced productive paddy's fields because of land use changes for other agricultural commodities and non-agriculture land use. Aim of this paper to review some causative factors influenced land use change from rain-fed paddy's fields to other uses in Bengkulu Province. Writing method was based on secondary data and information from some previous researches observing factors caused paddy's field conversion to other uses and other related references. The main reasons caused rain-fed rice fields converted to other agricultural land use and non-agricultural uses were water supply limited for intensive rice cultivation, harvested failure, other more profitable agricultural products, family labour lack, and high economic value for non-agricultural land uses. In short, future agricultural land use of rain-fed paddy's fields in Bengkulu Province toward uncertainty because of land use change to other agricultural cultivations and non-agricultural uses especially for settlement.
\end{abstract}

Keywords: Paddy's fields, erratic sustainability, causative factors, land use changes

\section{INTRODUCTION}

In Indonesia, the majority of farmers who are in the region with a monsoon climate, rice/paddy is planted on a technical irrigation where water availability throughout the whole year and there is an irrigation system flowing into the primary, secondary and tertiary channel [1]. Another system of water supply for rice plantation is the rain-fed with water sources depending on rainfall [2-3]. Avoiding harvest failure because of uncertainty water supply for rain-fed rice cultivation, farmers applied right setting of planting season [4]. However, some traditional farmers cannot be fully used as a reference in determining the planting season [5]. Also, farmers may consider either a reduction in planted area or schedule irrigation events so that plants do not encounter stress during sensitive growth stages [6]. Some farmers changed in agricultural land into coconut and rubber plantation [7], oil palm [8] and nonagriculture [9].

Understanding macro perspective, agricultural land use changes were accelerated by structural and economical transformations [10]. Furthermore, the structural transformation in economic activities that previously based on agriculture to shift forward more industrial business and from demographical perspective, population growth especially in urban areas causing agricultural land use converted to non-agricultural functions. Land use changes affect sustainable agricultural development through a set of multi-level, trans-sector and cross-policy issues [11]. Land-use and land-cover change is influenced by a variety of biophysical and societal factors operating on several spatial and temporal levels, and acting in intricate webs of place- and time-specific relationships [12]. Other word, land use change was affected by interlink endogenous (bio-geophysical, sociocultural and socio-economic conditions) with exogenous (normative values and societal land use demands) factors [13].

Rice farming was characterized as high risk but low return because agricultural products are dependent on often erratic weather conditions. If there are droughts or floods, farmers will lose money [14]. Furthermore, with the low price and high production cost (including labour, energy, and chemicals costs), the returns from rice farming are very small. Economic factors had the greatest impact on agricultural land use changes followed by social, management and policy making related, personal and technical factors [15]. Land use changes from rice fields to other uses were caused by some factors such as soil fertility degradation, water supply limited, pests and diseases attacks, other agricultural non rice attractiveness, and more profitable land use for non-agricultural sectors [16]. The deteriorating trends in the capacities of ecosystems to provide vital goods and services are already affecting the production potential of rain-fed paddy's fields as important food-producing zones. If these continue, impacts on rice yield would be worst at rain-fed rice in Indonesia, where both water and soil nutrients are least abundant.

In the last two decades, in one hand agricultural development policies focused to invest in potential and irrigated rice fields, mechanical equipment, export 
oriented monoculture crops therefore getting advantages from the policies were farmers occupying potential productive lands accessing to water, technological equipment, and capital resources [17].

On the hands, the farmer cultivated unfertile soils with lack of production input systems and management were ignored. The last condition seemingly was faced by rain-fed paddy farmers in Bengkulu Province. Nowadays, during a period of dramatic changes, water resources uncertainty, marginal soil properties, and various determinants delivering Bengkulu farmers to uncertainty rice production, there is a need to provide some support and encouragement to the farmers to move from their traditional high-water demand cropping and irrigation practices to modern, reduced demand systems and technologies.

\section{FUTURE UNCERTAINTY OF RICE PRODUCTION IN BENGKULU}

Rice production capacity in Bengkulu Province decreased drastically caused by natural use competitiveness of land and water sources, also land productivity level20].ling off. Global climatic changes further made worse to water supply uncertainty at whole year of rice planting periods depleting paddy field productivity followed by rice product alleviation. Harvested areas in Bengkulu Province in 2010, 2015, and 2019 were 133,629 ha, 128,833 ha, and drop to 64,406 ha, followed by rice production 516,868 tons, 578,654 tons, and drop to 296,472 tons [18]. Comparing to 2010, in 2019 rice harvested areas in Bengkulu Province lost about 57,474 ha or $47 \%$ and rice production lost about 219,896 tons or $42 \%$. In fact, coming down rice production in last ten years parallel with mount of rice demand for supplying high population growth predicted future staple food supply would face with uncertainties. Furthermore, Decreased paddy fields in Bengkulu based on regencies, the highest loses of rice harvested field was Central Bengkulu Regency dropped from 8,233 ha to 2,025 ha or about $75 \%$, followed by North Bengkulu Regency decreased from 19,674 ha to 5,897 ha or about $70 \%$, and Rejang Lebong Regency down from 15,967 ha to 5,567 ha or about $65 \%$. Harvested rice fields in other regencies such as Bengkulu City, Mukomuko, Kepahiang, Seluma, Lebong, Kaur, and South Bengkulu Regency were about 69\%, 50\%, 48\%, $40 \%, 32 \%, 30 \%$, and $8 \%$, respectively. In Lebong Regency, harvested rice areas in 2010 were 13,948 ha while in 2019 were 9,444 ha or decrease about $32 \%$. ). From 2011 to 2015, there were Lebong no positive growth of harvested rice fields and accumulated 5 years in those period occurred significantly negative growth [19]. Rice fields in Lebong Regency were considered as barn of rice supply in Bengkulu Province however recently went down comparing a long history before because of about 7,000 ha of rice field one period of rice planted only [20].

Seluma Regency was also also was considered as one of the highest rice production area in Bengkulu
Province and could be referent of staple food stability for closed regencies in Bengkulu [21]. Furthermore, from 40 agricultural commodities in Seluma, rice cultivation was a leading sector for agricultural activities, followed by rubber plantation. Harvested rice fields in 2010 covered 19,867 ha, in 2015 was 16,024 ha, and in 2019 was 11,850 ha. In a period of $2000-2010$, Seluma lost 765 ha of rice fields and in a period of 2010 - 2019, it lost 1,645 ha or accumulative rice field lost between 2000 to 2019 was 2,410 ha mostly for rubber and oil palm plantation [22]. Seluma occupying the second large rice fields in Bengkulu Province has 2 big water dams; Seluma and Penago water dams for irrigated rice fields at areas of previous 7,500 ha in 2009 and remaining 5,850 ha in 2012 [23]. Furthermore, Seluma regency government in an effort to local food security was hardly faced with rice field land use change.

Covered rice fields from 2009 to 2013 in North Bengkulu decreased was 2,987 ha otherwise fish ponds increased about 370 ha and at Padang Jaya sub-district rice field lost 725 ha and one of land use change factor was expansion of fish farming about 182 ha [24]. Arga Makmur as capital city of North Bengkulu continuing infrastructure and housing development, areas in past periods as productive rice fields convert to nonagricultural facilities [25]. ). In Kaur Regency harvested paddy fields in 2019 covered 6,572 ha dropped from 9,445 ha in 2010 or lost about 2,873 ha. Furthermore, in Bengkulu City, in 2010 areas of harvested rice field were 3,100 ha dropped in 2019 to be 957 ha rested only.

Land use changes in Bengkulu Province from rice fields to other function uses such as expansions of rubber and oil palm plantation, fish farming intensification, and non-agricultural infrastructure threaten not only staple food supply and food security but also multifunction of agricultural lands. Real economical values of rice fields much were much higher than conventional economically calculation value because paddy fields contributed to economical, socio-cultural, and ecological values.

\section{DRIVEN FACTOR INFLUENCING RICE FIELD CONVERSION IN BENGKULU}

Land use change from paddy fields to oil palm plantation by traditional farmers was actually revolutionary decision taken. Rice cultivation was considered required a lot of time and many natural defiance causing harvested failures whereas plated rice often faced with lower revenues. Learn from oil palm farmers, cultivating oil palm seemingly was no wasting time for cultivation, easier in cultivation management, no ecological barrier, and higher benefit gained.

Driving forces of land-use change mainly accelerated by political economy and political structure [26]. The last few years had seen big increases in land values as the driving force for land use change [27]. Furthermore, in some states, the price of land may represent up to $80 \%$ of property in agriculture. Land rent 
in the classical sense is income derived from selling the services of a unit of land, independent of the services of capital or labour. It represents the economic return that accrues to land for its use in production. Land rent in simple definition, economical surplus in form of net income taking from a land area per year as a result of an activity on that land. Main reason of land use change from paddy field was economic value much lower than that of oil palm [28]. Broad determinants affected land use change from paddy fields to other uses in Bengkulu revealed in Table 1.

Table 1. Driven Factors Influencing Paddy Fields Conversion in Bengkulu

\begin{tabular}{|l|l|l|c|c|}
\hline \multicolumn{1}{|c|}{ Attributes } & \multicolumn{1}{|c|}{ Regency } & \multicolumn{1}{|c|}{ Conversion to } & Sig & Ref. \\
\hline Irrigation & Seluma & Oil Palm & $0.016^{*}$ & {$[29]$} \\
\hline & $\begin{array}{l}\text { North Bengkulu } \\
\text { South Bengkulu }\end{array}$ & Oil Palm & $0.002^{* *}$ & {$[30]$} \\
\hline & Lebong & Social Facilities & $0.034^{*}$ & {$[31]$} \\
\hline & Bengkulu City & Social Facilities & $0.015^{*}$ & {$[32]$} \\
\hline Harvested failure & Seluma & Oil Palm & $0.016^{*}$ & {$[29]$} \\
\hline & North Bengkulu & Oil Palm & $0.009^{* *}$ & {$[30]$} \\
& South Bengkulu & & & {$[33]$} \\
\hline & Kaur & Social Facilities & $0.023^{*}$ & {$[31]$} \\
\hline & Lebong & Social Facilities & $0.041^{*}$ & {$[29]$} \\
\hline Labor limited & Seluma & Oil Palm & $0.027^{*}$ & {$[29]$} \\
\hline & Seluma & Oil Palm & $0.056^{*}$ & {$[33]$} \\
\hline & Kaur & Social Facilities & $0.018^{*}$ & {$[31]$} \\
\hline & Lebong & Social Facilities & $0.020^{*}$ & {$[32]$} \\
\hline Extension activity & Bengkulu City & Social Facilities & $0.026^{*}$ & {$[30]$} \\
& $\begin{array}{l}\text { North Bengkulu } \\
\text { South Bengkulu }\end{array}$ & Oil Palm & $0.020^{*}$ & {$[30]$} \\
\hline $\begin{array}{l}\text { Regulation } \\
\text { knowledge }\end{array}$ & $\begin{array}{l}\text { North Bengkulu } \\
\text { South Bengkulu }\end{array}$ & Oil Palm & $0.017^{*}$ & {$[33]$} \\
\hline & Kaur & Social Facilities & $0.015^{*}$ & {$[32]$} \\
\hline Family dependent & Bengkulu City & Social Facilities & $0.039^{*}$ & \\
\hline
\end{tabular}

Ecological determinants driven land use change from paddy field to rubber and oil palm plantation were mainly water supply limited, pest and diseases attacks, and infertile soils. Environmental factors accelerated conversion of rice areas to other uses were irrigation water supply limited especially in dry seasons and high attacks from various pests and diseases such as brown planthopper, stem borer, and rats. [34] pigs, birds, golden snail. Paddy consumed water in high quantity and much more than other food crops therefore lack of water availability from irrigation facilities could determine rice cultivation. Lack of water availability from irrigation channels was caused by less maintenance of irrigation infrastructures and low participation from farmers to maintain irrigation channels. Lack of water supply for paddy cultivation often caused rice harvested failure therefore for continuous rice cultivation needed water supply throughout the year. Irrigated rain-fed rice fields required a large investment for irrigation infrastructures such as irrigation channels because the fields lay far from water sources. Other technological watering rice fields implemented groundwater pump but it was very expensive too. A main reason for farmers in Seluma Regency converted rice field function to oil palm plantation was not enough water supplied from irrigation channels for rice cultivation throughout the year [35]. Harvested failures caused of pests and diseases attack discouraged farmers to continue rice cultivation and be a driven factor for converting to other uses.

In Seluma Regency, land rent for rice fields was in average Rp. 11,742,521 ha $\mathrm{hr}^{-1}$, while that for oil palm in average Rp. 15,533,369 $\mathrm{ha}^{-1} \mathrm{yr}^{-1}$ with PVNR-land rent value for rice cultivation was Rp. 106,587,332 $\mathrm{ha}^{-1}$ and that for oil palm $118,195,250 \mathrm{ha}^{-1}$ therefore PVNR-land rent from oil palm plantation $10.89 \%$ higher than that from rice cultivation [29]. In North Bengkulu and South Bengkulu Regency, land rent for rice fields was in average Rp. 7,650,590 ha- $\mathrm{yr}^{-1}$, while that for oil palm in average Rp. 11,104,076 ha $^{-1} \mathrm{yr}^{-1}$ with PVNR-land rent value for rice cultivation was Rp. $69,444,701 \mathrm{ha}^{-1}$ and that for oil 
palm 74,791,984 ha ${ }^{-1}$ [30]. Based on PVNR-land rent above could be concluded that economical viewpoint of rice field conversion to oil palm plantation. That was a logical decision from farmers because of benefits from oil palm plantation higher than rice field cultivation. Therefore, land value perceptions from farmers significantly influent their decision for land use change and agricultural activities on their lands. Based on farmer perfectives, rice field conversion was highly affected by economical land values in Arga Makmur, capital city of North Bengkulu, in South Kaur, capital city of Kaur, in Lebong, Seluma, Bengkulu City.

Production costs of agricultural inputs such as fertilizers, pesticides, seeds significantly affected rice field conversion. Fertilizers are the main production input for agriculture sector. Farmers often face with fertilizers distribution not on time availability especially subsidized fertilizers. Distribution system of subsidized fertilizers directed to the farmer organization was not guarantee availability of fertilizers on time and sufficient amounts. Farmers should have financial enough to redeem the fertilizers proposed otherwise "the second hands" paid for the fertilizers took over. Fertilizers on "the second hands" would be public goods that could be used by all who had excessive financial to pay subsidized fertilizers. The increasing production costs for rice cultivation were determinant factors caused rice field land use change to oil palm plantation and rubber in Seluma Regency In depth study in Kungkai Baru Village, Air Periukan sub-district, Seluma Regency [36] ) revealed various determinants caused land use change from rice fields to oil palm plantation from $85 \%$ having a desire to convert their farm such as economical reason $58.4 \%$, technical aspects $19.4 \%$, and environmental constraints $22.2 \%$. Furthermore, from whole 14 determinants accelerating land conversion consisted of 5 economic reasons namely 1) selling price of rice when harvest periods $(23.1 \%), 2)$ continuous production in each 2 weeks harvest (13.3\%), 3) higher income of oil palm plantation $(10.2 \%)$, 4) more guaranteed price of oil palm bunches (9.9\%), and 5) lower production cost of oil palm plantation (1.9\%). Technological perspectives for land use change from the study depicted that 1) long lasting oil palm production $(13.3 \%), 2)$ harvesting techniques and post-harvesting more complicated $(2.4 \%)$, oil palm cultivation more simple $(2.2 \%)$, and agricultural inputs not available on time (1.5\%). While, from ecological constraints accelerating rice field conversion were 1) more suitable lands for oil palm $(6.9 \%)$, pests and diseases attacks often causing harvesting failure $(6.7 \%)$, lack of irrigation facilities (4.9\%), having oil palm plantation occupying higher bargaining position in societies $(2.7 \%)$, and lower labor demand in oil palm plantation $(1.0 \%)$.

Institution and policies could be driven factors accelerated land conversion from rice field to other functions in Bengkulu Province. Government rules for sustainable land use seem only as an appeal without followed by supervision and penalty from government. Also, regional autonomy law provided a broad independency to local government deciding regional development planning and implementation. In this case, plantation sub sector of agricultural and social development giving more gross regional income could be higher priority than food crops cultivation therefore local government not consider enough central government regulations of sustainable land use. In short, if all driven factors caused rice filed land use change to other functions in Bengkulu Province, future rice production for population staple food demand face with uncertainty supply and could disrupt food security stabilities.

\section{CONCLUSION}

Decreasing paddy field areas in Bengkulu Province still continue because of land conversion to oil palm and rubber plantation, fish pond farming, and social infrastructures. Lose of rice field threaten staple food availability and then disturb food security stability. Driven factors causing paddy field conversion mainly economic perspectives were; low land rent and sufficient supply of agro-inputs in rice field, ecological constraints such as harvested failures because of water supply limited, and pests and diseases attacks. While institution and policies determinants were implementation of sustainable agricultural land regulations and immeasurable extension staff activities.

\section{REFERENCES}

[1] Y. Apriyana, Y. Sarvina, E.R. Dewi, and A. Pramudia, A. 'Farmer adaptation strategy in paddy field affected by climate variability in monsoon regions.', Asian J Agric, vol. 1 no. 1, pp. 9-16, 2017 ,

doi: https://doi.org/10.13057/asianjagric/g010103

[2] Y.P.A. Sinaga and R.M. Sembiring. 'Evaluasi kesesuaian lahan untuk padi sawah tadah hujan (Oryza sativa L) di Kecamatan Muara Kabupaten Tapanuli Utara.', JAET, vol. 2, no. 1, pp. 10421048 ,

2014

https://media.neliti.com/media/publications/99624ID-evaluasi-kesesuaian-lahan-untuk-padi-saw.pdf

[3] H. Suganda, E.P. Paningbatan, L.C. Guerra and T.P. Tuong. 'Effect of position of rainfed rice field in a toposequence on water availability and rice yield in Central Jawa, Indonesia' Jurnal Tanah dan Iklim, vol. 2, no. 1, pp. 30 - 42, 2003, doi: https://dx.doi.org/10.2017/jti.v0i21.268

[4] R.L. Naylor, D.S. Battisti, D.J. Vimont, W.P. Falcon, and M.B. Burke. 'Assessing risks of climate variability and climate change for Indonesian rice agriculture.', Proc Natl Acad Sci U $S A$, vol. 104, no. 19, pp. 7752-7757, 2007, doi: https://dx.doi.org/10.1073\%2Fpnas.0701825104

[5] E. Runtunuwu,H. Syahbuddin, I. Las, and I. Amien. 'Utilizing cropping calendar in coping with climate change.', Ecolab, vol, 5, no. 1, pp. 1 - 44, 2011. 
http://ejournal.forda-mof.org/ejournallitbang/index.php/JKLH/1476/1341.

[6] K.C. Dejonge, J.C. Ascough II, M. Ahmadi, A.A. Andales, and M. Arabi. 'Global sensitivity and uncertainty analysis of a dynamic agro-ecosystem model under different irrigation treatments.', Ecological Modelling, vol. 231, pp. 113-125, 2012, doi: https://doi.org/10.1016/j.ecolmodel.2012.01.024

[7] F.I. Dolly, Kismartini, and H. Purnaweni. 'The land use change from agriculture to non-agricultural in Bungo Regency,Jambi Province, Indonesia.', E3S Web of Conferences, vol. 31, no. 09019, 2018. https://doi.org/10.1051/e3sconf/20183109019

[8] A. Fahri. 'Aplikasi pendekatan land rent dalam menganalisis alih fungsi lahan sawah menjadi kebun sawit.', Informatika Pertanian, vol. 25, no. 1, pp. $1 \quad-\quad 8, \quad 2016, \quad$ doi: http://dx.doi.org/10.21082/ip.v25n1.2016.p9-20

[9] P.A. Permatasari, A.Fatikhunnada, Liyantono, Y. Setiawan, Syartinilia, and A. Nurdiana. 'Analysis of agricultural land use changes in Jombang Regency, East Java, Indonesia using BFAST method.', Procedia Environmental Sciences, vol. 33, pp. $27-35, \quad 2016$, doi: https://doi.org/10.1016/j.proenv.2016.03.053

[10] Ashari. 'Tinjauan tentang alih fungsi lahan sawah ke non sawah dan dampaknya di Pulau Jawa.', Forum Penelitian Agro Ekonomi, vol. 21, no 2. pp: 83 - 98, 2003, doi: http://dx.doi.org/10.21082/fae.v21n2.2003.83-98

[11] T. Hermanns, K. Herlming, H.J. Konig, K. Schmidt, Q. Li, and H. Faust. 'Sustainability impact assessment of peatland-use scenarios: Confronting land use supply with demand.', Ecosystem Services, vol. 26, pp. 365-376, 2017, doi: http://dx.doi.org/10.1016/j.ecoser.2017.02.002

[12] H. Briassoulis. 'Analysis of Land Use Change: Theoretical and Modelling Approaches.', Web Book of Regional Science, no. 3, 2019. https://researchrepository.wvu.edu/rri-web-book/3

[13] K. Helming, K. Diehl, H.Bach,O.Dilly, B. König, T. Kuhlman, M. Pérez-Soba, S. Sieber, P. Tabbush, K. Tscherning, D. Wascher, H. Wiggering. 'Ex ante impact assessment of policies affecting land use, Part A: analytical framework.', Ecol. Soc. Vol 16, pp. 29, 2011. https://www.jstor.org/stable/26268844

[14] P. Ngammuangtueng, N. Jakrawatana, P. Nilsalab, and S.H. Gheewala.'Water, Energy and Food Nexus in Rice Production in Thailand'. Sustainability, 2019, doi: http://dx.doi.org/10.3390/su11205852.

[15] M.S. Allahyari, A. Poshtiban, and V.Koundinya. 'Effective factors on agricultural land use change in Guilan Province, Iran.', MJSS, vol. 4, no.11, pp. 44-750, 2013, doi: 10.5901/mjss.2013.v4n11p744
[16] M.R. Mamondol. 'Multifungsi pertanian padi sawah di Kabupaten Poso.', Jurnal Envira, vol. 2, no. $1, \quad$ pp. 1-11, 2017 https://media.neliti.com/media/publications/99624ID-evaluasi-kesesuaian-lahan-untuk-padi-saw.pdf

[17] FAO. 'The State of the World's Land and Water Resources for Food and Agriculture: Managing Systems at Risk'. Branch, Office of Knowledge Exchange, Research and Extension, FAO, Viale delle Terme di Caracalla, 00153 Rome, Italy, 2011.

[18] BPS-Statistics Bengkulu. 'Luas Panen, Produktivitas, dan Produksi Padi. 2010 - 2015, 2018-2019, 2020.

[19] A. Nurrokhman. 'The country sermon about paddy field: Implementation of sustainable food protection policy in Lebong Regency, Bengkulu Province.', Jurnal Pertanahan, vol. 8, no. 2, pp. 99 - 116, 2018.

[20] W. Wibawa, Ruswendi., Miswarti, and $\mathrm{H}$. Kusnadi. 'Inovasi Teknologi dan Kelembagaan Prima Tani pada Agroekosistem Lahan Sawah Semi Intensif di Kabupaten Lebong. Laporan Tengah Tahun 2009.', Balai Pengkajian Teknologi Pertanian Bengkulu, 2009 http://bengkulu.litbang.pertanian.go.id/ind/images/ dokumen/lapteng2009/.pdf

[21] Hardiyanto. L. Rospida, and E. Rahmantyo. 'Analisis Komoditas Unggulan Sektor Pertanian Di Kabupaten Seluma Provinsi Bengkulu.', Undergraduated Thesis, Universitas Bengkulu, 2013, http://repository.unib.ac.id/id/eprint/8384

22] Mujiono and I. Fitria. 'Spatial model paddy field to support sustainable food farming policy in Seluma District.', Agritrop, vol. 17, no. 1, pp. 113 - 123, 2019,

http://jurnal.unmuhjember.ac.id/index.php/AGRIT $\underline{\text { ROP }}$

[23] R.T. Yanti, M. Ridwan, and I. Rospida. 'Analisis alih fungsi lahan pertanian tanaman pangan padi sawah ke sector perkebunan kelapa sawit dan karet serta pengaruhnya terhadap produksi padi di Kabupaten Seluma Provinsi Bengkulu.', JEPP, vol. 5, no. 2, pp. $64-75,2013$ http://repository.unib.ac.id/id/eprint/11032

[24] D. Yuliansyah, D, K. Sukiyono, and A. Sitorus. Analisis fungsi lahan sawah ke lahan perikanan darat sebagai respon kebijakan pengembangan minapolitan di Kabupaten Bengkulu Utara Provinsi Bengkulu; Case study di Kecamatan Padang Jaya. Master Thesis, Universitas Bengkulu, 2015, available: http://repository.unib.ac.id/id/eprint/10680

[25] E. Siswanto. 'Kajian Harga Lahan dan Kondisi Lokasi Lahan Pemukiman di Kecamatan Arga Makmur Kabupaten Bengkulu Utara.', Master Thesis, Program Pascasarjana Universitas Diponegoro, Semarang, 2007, available: 
http://eprints.undip.ac.id/17241/1/EDDY_SISWA NTO.pdf

[26] K. Hubacek and J. Vazquez. 'The economics of land use change'. IIASA. Schlossplatz 1 A-2361 Laxenburg, Austria, 2002, available: http://pure.iiasa.ac.at/6770

[27] F. Strelecek, J. Lososova, and R. Zdenek, R. 'The relations between the rent and price of agricultural land in the EU countries.', Agric. Econ - Czech, vol. 56, no. 12, pp. 558-568, 2010, available: https://www.agriculturejournals.cz/publicFiles/130 2010-AGRICECON.pdf

[28] A. Fahri. 'Aplikasi pendekatan land rent dalam menganalisis alih fungsi lahan sawah menjadi kebun sawit.', Informatika Pertanian, vol. 25, no. 1, pp. $1 \quad-\quad 8, \quad 2016, \quad$ doi: http://dx.doi.org/10.21082/ip.v25n1.2016.p9-20

[29] Hamdan. 'Ekonomi Konversi Lahan Sawah menjadi Kebun Kelapa Sawit di Kecamatan Seluma Selatan Kabupaten Seluma Provinsi Bengkulu.', Master Thesis, Pascasarjana Institut Pertanian Bogor, Bogor, 2012, available: https://adoc.tips/ekonomi-konversi-lahan-sawahmenjadi-kebun-kelapa-sawit-di-k.html

[30] D. Sugandi, A. Ishak, and Hamdan. 'Faktor-faktor yang Mempengaruhi Alih Fungsi Lahan Sawah Menjadi Kebun Kelapa Sawit dan Strategi Pengendaliaannya di Bengkulu.', 2012, available: http://bengkulu.litbang.pertanian.go.id.pdf

[31] Hofizer, S. 'Analisis Faktor Alih Fungsi Sawah, Strategi Pengendaliannya dan Pengaruhnya terhadap Produksi Padi di Kabupaten Lebong.', Master Thesis, Universitas Benkulu, 2019.

[32] S.S. Aprillya, 'Analisis faktor penyebab dan strategi pengendalian alih fungsi sawah menjadi perumahan dan dampaknya terhadap lingkungan di Kota Bengkulu.', Master Thesis, Universitas Bengkulu, 2019.

[33] Yurizal, E. 'Analisis faktor penyebab dan dampak alih fungsi sawah menjadi lahan perumahan terhadap produksi padi dan lingkungan di Kecamatan Kaur Selatan, Kabupaten Kaur.', Master Thesis, Universitas Bengkulu, 2020.

[34] Suharyanto, J. Rinaldy, and N.N. Arya. 'Analisis resiko produksi usaha tani padi sawah di Provinsi Bali.', AGRARIS: Journal of Agribusiness and Rural Development Research, vol.1, no. 2, pp. 70 $77.2015, \quad$ available: https://media.neliti.com/media/publications/225791 .pdf

[35] A.Ishak, W.E. Putra, and J. Hendra. 'Diversifikasi pola nafkah dan struktur pendapatan petani (Studi kasus pada pelaku alih fungsi lahan sawah ke sawit di Kelurahan Rimbo Kedui, Seluma - Bengkulu). Prosiding Seminar Nasional Agroinovasi Spesifik Lokasi Untuk Ketahanan Pangan Pada Era Masyarakat Ekonomi ASEAN.', 2017, available: http://repository.pertanian.go.id/handle/123456789/ $\underline{6959}$

[36] U.P. Astuti, W. Wibawa, and A. Ishak. 'Faktor yang mempengaruhi alih fungsi lahan pangan menjadi kelapa sawit di Bengkulu: Kasus petani di Desa Kungkai Baru.', Prosiding Seminar Nasional Budidaya Pertanian Urgensi dan Strategi Pengendalian Alih Fungsi Lahan Pertanian, Bengkulu, pp. 189 - 195, 7 Juli 2011. ISBN 978602-19247-0-9, available: 